\title{
Is Germany a Leader in EU? An Examination Trough Its Environmental Policies and Actions
}

\author{
Hao Yang ${ }^{1, *}$ \\ ${ }^{1}$ School of Foreign Language, Shanghai Jiao Tong University, Shanghai 201100, China \\ *Corresponding author email: crystalyh@sjtu.edu.cn
}

\begin{abstract}
As an important member of the European Union, Germany is well recognized as a leader in economic and political fields. On the climate and environment protection, Germany's performance is less impressive as it has failed its target in 2020. In terms of environmental policy, it has been questioned if Germany's relationship with the EU is similar to other perspectives. For dealing this question, the article first introduces German domestic environmental policies, then compares them with assessments from international organizations and finally draws a conclusion from the different attitudes of international organizations and Germany itself towards German environmental policies that Germany is struggling to reach its targets instead of playing a leading role.
\end{abstract}

Keywords: Germany, European Union, environmental policy, carbon neutrality

\section{INTRODUCTION}

Germany is one of the six founding members of European Union. For a long time, Germany has been a strong leader in the European Union. As the largest economy in Europe and the fourth largest in the world, some scholars called Germany as the core economic strength of Europe [1]. The geographical, demographical, economic and financial sizes make it inescapable that Germany is Europe's leading state [2]. Germany's role is sometimes controversial. During the debt crisis, although Germany played an irreplaceable role, firmly opposing to issuing common bonds, insisting on serious fiscal discipline and pushing austerity policies, these actions were considered by many as putting Germany's own interests above those of Europe and lacking strategic vision [3]. Similarly, Germany plays an important role in EU with regards to climate change reduction and environmental policies but this role is also controversial. As Germany failed its goal for Greenhouse Gas (GHG) reduction, which promised to achieve at least a $40 \%$ cut in GHG emissions by 2020 compared with the base year of 1990 [4], the leading role of Germany in EU in terms of environmental policies is doubted: does Germany still play a leading role in the EU or does German vacillate and even block the EU's progress on environmental issues? As for Germany's role in the EU, most scholars focus on the perspective of economy or EU integration. There hasn't been a lot of research on environmental issues. This paper will examine the relationship between Germany and the EU through their interactions in respect of environmental policies and mechanisms.

The article will be structured in the following way. First, the German domestic environmental policies will be introduced. Then, the article will discuss assessments from different international organizations about Germany. Finally, the article will draw a conclusion with regarding to the relationship between EU and Germany in terms of environmental policies.

\section{GERMAN ENVIRONMENTAL POLICIES AND ACTIONS}

The Paris Agreement is a legally binding international treaty on climate change. It was adopted at COP 21 in Paris, on 12 December 2015 and entered into force on 4 November 2016. Its goal is to hold global warming to well below 2, preferably to 1.5 degrees Celsius, compared to pre-industrial level [5]. In order to limit global warming to 1.5 degrees Celsius, a threshold that the Intergovernmental Panel for Climate Change (IPCC) has suggested, carbon neutrality by mid-21st century is essential [6]. This target is also laid down in the Paris agreement signed by 192 parties (191 countries and EU) today. As a member of EU, Germany has set its own environmental policy under the guideline by the framework of EU energy and climate policies. 
Germany spent EUR 19.185 billion ( $0.6 \%$ of GDP) on environmental protection in 2016, an increase of $6.7 \%$ from 2015. Between 2012 and 2016, general government funding for environmental protection came to EUR 88,849 billion [7].

Germany has also introduced coherent laws on environmental protection and carbon emission reduction, such as the Renewable Energy Act (2000), the Eco-tax (1999), the Cogeneration Act(2002), the Energy Conservation Act (2001), the Energy Conservation Ordinance (2014), and the Ecodesign Directive (ErP 2005).

The German policy of vastly increasing its dependence on highly-subsidized renewables is known as the Energiewende (energy transition) and is based on the Energiekonzept (energy concept) policy published late in 2010, as well as the Renewable Energy Sources Act (Erneuerbare Energien Gesetz, EEG) passed in 2000 [8]. Its target is to achieve at least a $40 \%$ cut in GHG emissions by $2020,55 \%$ by $2030,70 \%$ by 2040 and $80-$ $95 \%$ by 2050 , at which point the country expects to be mostly GHG-neutral [8]. In 2017, Germany Federal Foreign Office published a brochure called "Making the Energiewende a success story thanks to strong local authorities". According to this brochure, Energiewende has received a big success because states and cities in Germany all have contributed a lot to this policy. For example, in Munich the Stadtwerke München public utility company promised that by 2025 , the entire electricity needs of Munich will be met by renewable energy sources. Stadtwerke Düsseldorf is building a new highly efficient combined-cycle power plant in the port of Düsseldorf, which, in 2016, would provide Düsseldorf with heat and electricity with an overall efficiency of over $85 \%$.

\section{ASSESSMENTS OF GERMANY FROM INTERNATIONAL ORGANIZATIONS}

Germany is quite optimistic about what they have achieved so far, and set more ambitious goal for future. According to the study of Prognos, Öko-Institut, Wuppertal Institut, published on April 26, 2021, Germany can achieve carbon neutrality five years earlier than 2050, namely five years earlier than the deadline suggested by the IPCC. The earlier achievement could thus reduce greenhouse gas emissions by a further billion tons [9].

However, the reality may not be as rosy as Germany thinks. Germany has already lost the track to meet its near-term emissions reduction targets set in 2020 which promised to achieve at least a $40 \%$ cut in GHG emissions compared with the base year of 1990 [4]. Despite the failure of previous target, Germany still decides to raise the goal for 2030 from $55 \%$ to $65 \%$ and believes that it is "an ambitious but achievable interim target" [9].
Based on the review of the calculations performed for the 2050 study, agriculture and waste sectors are unable to make contributions to additional emission reductions and the additional reductions of transport and building sectors are also quite limited (only 5 million tons) [9]. Thus, industry and energy sectors need to undertake a greater task of emission reductions- 17 and $77 \mathrm{Mt} \mathrm{CO}_{2} \mathrm{e}$, respectively [9]. But in the past few years, the energy sector, in particular, the electricity sector, has been shouldering a sizeable share of the Energiewende's costs and progress [4].

The doubt on Germany's leading role in climate change in EU is also shown in the assessments from many international agencies and organizations, such as Climate Action Tracker, EU, the International Energy Agency.

\subsection{Climate Action Tracker (CAT)}

The Climate Action Tracker is an independent scientific analysis that tracks government climate action and measures it against the globally agreed Paris Agreement aim of holding warming well below $2^{\circ} \mathrm{C}$, and pursuing efforts to limit warming to $1.5^{\circ} \mathrm{C}$ [10]. It is founded by several climate science research institutes, including Climate Analytics, NewClimate Institute and the Potsdam Institute.

According to the assessment of the Climate Action Tracker (CAT), the overall assessment for Germany is "insufficient". CAT projected that implemented and announced policies and actions will lead to emissions reductions of between 54-57\% below 1990 levels by 2030 [11], which still falls short of Germany's 2030 target of at least a $64 \%$ reduction below 1990 levels.

Two problems stand out. First, German electricity mix depends heavily on fossil fuels. Since 2015, the quantity of coal generation has been reduced in half, but natural gas has doubled its share and total fossil generation reduced only by $31 \%$. German power plants emitted about $10 \mathrm{MtCO} 2 \mathrm{e}$ more in the first quarter of 2021 than in the same period in the previous year, which could potentially foreshadow rising emissions in 2021. Around two thirds of electricity generation emissions in 2020 came from lignite and hard coal-fired power plants, and $16 \%$ of the country's total emissions still came from power and heat generation from coal-fired power plants. Second, Germany's scheduled 2038 coal phase-out is not $1.5^{\circ} \mathrm{C}$ compatible. In 2020 , about $16 \%$ of total German emissions still came from power and accompanied heat generation from coal-fired power plants. While Germany has agreed on a coal phase-out by 2038 and the first rounds of phase-out tendering have been held in 2020 and 2021 , the schedule is not fast enough to reach the new target [11].

The "insufficient" overall rating shows that Germany's environmental policy needs a marked improvement, especially in fair share target and climate 
finance. Germany's target is quite lax and it is not consistent with the $1.5^{\circ} \mathrm{C}$ goal. In another word, if other countries followed Germany's target, then the global warming would reach over $2^{\circ} \mathrm{C}$ and up to $3^{\circ} \mathrm{C}$.

Even though Germany's international public climate finance has outstripped most developed countries, the CAT still considers German climate finance as "insufficient". The reason is that Germany has committed to increasing its climate finance, but contributions are not enough compared to its fair share as assessed by the CAT. Germany needs to increase its international climate finance contributions significantly in the period post2020 and urgently stop funding fossil fuels abroad.

\subsection{European Union}

According to the Environmental Implementation Review 2019 of Germany which is an official report published by the Directorate-General for Environment, European Commission, Germany falls behind in several perspectives.

As a member of the European Union, Germany has national targets for reducing emissions outside the EU Emissions Trading System (ETS). By 2020, non-ETS emissions are supposed to be reduced by $14 \%$ compared with 2005 , and by $38 \%$ by 2030 . However, Germany failed the target in 2020 [12].

The Circular Economy Action Plan is one of the main building blocks of the European Green Deal, Europe's new agenda for sustainable growth [12]. Its implementation in Germany is not so ideal. In the perspective of circular use of material, one of the key indicators for monitoring the transition to a circular economy, Germany scored $11.4 \%$ in 2017 , below the EU average of $11.7 \%$. And for another perspective - resource productivity - Germany remains in the mid-range of Member States. Generally, there is clear support in German society and government for strengthening and further developing circular economy, which is confirmed in the coalition agreement in 2018. However, current programs related to circular economy are the 2016-2019 ProgRess II resource efficiency program (Deutsches Ressourceneffizienzprogramm ProgRess II) and the national program for sustainable consumption (Nationales Programm für nachhaltigen Konsum), both of which are not dedicated program for circular economy. Germany still lacks such dedicated program at the national level.

In terms of biodiversity strategy, the Birds and Habitats Directives of EU require Member States to establish a national network of Natura 2000 sites. In Germany, minor insufficiency is observed in the latest assessment for Natura 2000. By the end of 2017, the network covered $15.5 \%$ of Germany's land area while the average of EU is $18.2 \%$ [7]. Nature protection in Germany falls within the competence of its 16 states
(Länder) and the federal authorities (Bund) are responsible for the exclusive economic zone. The main pressures of designating Natura 2000 sites come from agriculture in the form of changes of agricultural practices and intensification. The agricultural sector benefits from exemptions from many nature protection regulations. For example, "good agricultural land use" and "good farming practice" activities are exempted from national nature protection provisions in the Länder [7].

\subsection{The International Energy Agency (IEA)}

The IEA examines the full spectrum of energy issues including oil, gas and coal supply and demand, renewable energy technologies, electricity markets, energy efficiency, access to energy, demand side management and much more [4]. The Report Germany 2020 Energy Policy Review published by IEA examines the present situation of Energy transformation in Germany and put forward relevant suggestions.

According to the report, the Energiewende has been in operation for nearly a decade, but Germany is still struggling to meet its GHG targets. The main reason is the uneven progress across sectors, with notable challenges in transport and heating.

It is undoubted that Germany's Energiewende received quite obvious effort in electricity generation. Renewables have mainly replaced a large share of nuclear over the last decade, but coal remains the largest source of electricity [4].

As a core sector of the Energiewende, Germany plans to further expand the role of renewables in electricity generation. Specifically, in the 2010 Energy Concept, the country aimed for renewables to account for $35 \%$ of gross electricity consumption by 2020 and overachieved this with $38 \%$ in 2018 and $44 \%$ in the first half of 2019 . The German government initially planned to further increase the share of renewables in electricity to $50 \%$ by $2030,65 \%$ by 2040 and $80 \%$ by 2050 . But according to the new coalition agreement of March 2018, as affirmed by the climate cabinet, the government is now planning to speed up the growth, to reach a share of $65 \%$ renewable electricity by 2030 (contingent on a corresponding expansion in grid capacity) [4].

Despite its progress in power sector, German government need more efforts in other sectors. In the perspective of transport, which is the largest barrier on German emission reduction, diesel vehicles are still widely used and has contributed to rising air pollution [4]. The decarbonization plan for heating sector is still process, while this sector accounts for over $50 \%$ of final energy consumption and $40 \%$ of emissions [4]. However, challenges have appeared as the use of renewable power steadily grows, which is imbalanced power supply. 
Most wind capacity is located in northern Germany, whereas most demand comes from metropolitan and industrial areas in the south and west of the country. Due to increased generation from wind and solar, network constraints preventing transmission from the north to the south, delays in grid expansion, and the lack of multiple bidding zones, northern states are facing power surpluses and southern ones are experiencing electricity overspending, an imbalance that will worsen as the last of the country's commercial nuclear power plants in the south and northwest close and wind power generation is put into use in the north. The imbalance has resulted in "re-dispatch" measures in the south, where grid operators order power stations to ramp up output to compensate for procured electricity that cannot make it south, and curtailment in the north, where grid operators order generators to shut down to avoid congestion This imbalance costs consumers hundreds of millions of euros annually. This year, German electricity bills are higher than ever because of higher energy prices and inflation. Germany is set for its "most expensive winter".

In terms of green taxation, Germany's revenues from environmental taxes are among the lowest in the EU, accounting for $1.86 \%$ of GDP in 2016 (EU average: $2.44 \%$ ), down from $2 \%$ in 2014. Energy taxes account for $1.54 \%$ of GDP, compared with an EU average of $1.88 \%$ [13].

\subsection{The Organization for Economic Co- operation and Development (OCED)}

The OECD Economic Surveys on Germany in 2020 pointed out the deficiency in waste sector.

Germany plays a leading role in OECD in recycling. As Germany progresses on climate policy and green investment, moving towards a more circular economy would reduce materials use and environmental impacts by avoiding wasteful use, and encouraging reuse, recycling and shared use. After 2005, Germany has set high recycling standards and the result is obvious. The landfilling of untreated waste is almost non-existent. A new Packaging Act in 2019 set ambitious recycling targets and required registering to a new national authority before putting packaging on the market. However, according to OCED survey, German waste generation has not decreased and even increased between 2010 and 2016, mainly due to construction and demolition, which accounts for nearly $60 \%$ of total waste [29]. Multiple waste generation such as incineration, recycling and composting is above most OCED countries. Germany recycles about two thirds of its solid waste which has actually already reached the 2035 EU target of $65 \%$. However, this level has started to stabilize, which suggests that more efforts are needed to improve the recycling rate.
As the largest waste stream, the construction industry is a major target for circular approaches. Although about $90 \%$ of construction and demolition waste is recycled, the building sector hardly uses any secondary materials. Therefore, recycling of construction and demolition waste is mostly converting valuable products into lowvalue raw materials. Taxes or levies on virgin raw materials used in construction, such as gravel and sand, could increase demand for recovered waste

\section{DISCUSSION}

From the evaluation of the above four organizations, it is found that in environmental policies Germany does not play a leading role like other aspects. On the contrary, Germany is struggling to meet the targets it has promised before.

The result disagrees with some researchers who have found that Germany's climate governance policy and regulatory system is gradually improving, achieving "peak carbon emissions" and "decoupling" economic growth from carbon emissions [14]. These findings may help us rethink the role of Germany in EU.

\section{CONCLUSION}

According the evaluation of international organizations and institutes mentioned above, Germany still faces serious challenges on the road to carbon neutrality. However, despite the failure in some targets, Germany still chose to act bold and set even more ambitious goals for future, which promised to achieve at least a $65 \%$ cut in GHG emissions by 2030 and reach carbon neutrality 5 years earlier as 2050 .

However, Germany's conservative action is quite opposite of its ambitious goals. Electricity sector has undertaken a large number of emission reduction tasks in the past, but in order to reach the 2045 goal, it is time to change the uneven distribution of targets and put more emphasis on other sectors like agriculture, waste, transport and heating sectors. But the 2050 study still expects the electricity sector to make a major contribution to carbon reduction.

The shifting in environmental policies cannot be seen. In the 2021 general election, Germany's Social Democratic Party (SPD) and the Alliance Party (CDU) still hold the majority of votes. Although votes for the Green Party have significantly increased compared to before, ranked third, but the Party is still unable to make significant decisions in the government.

\section{REFERENCES}

[1] Li, H. (2014b, January 5). Germany: European economic "engine." Imp-Exp Executive, 01 https://kns.cnki.net/kcms/detail/detail.aspx?FileNa me $=$ SJJD201401013\&DbName $=$ CJFQ2014 
[2] Wallace, W. (1995). Germany as Europe's Leading Power. The World Today, 51(8/9), 162-164.

[3] Jin, L. (2020, August 16). Entrusted at a critical moment, can Germany lead the EU out of the crisis. World Knowledge, 16.

[4] Germany, I. E. A. (2020). Energy Policy Review. International Energy Agency: Paris, France.

[5] The Paris Agreement. (n.d.). UNFCCC Sites and Platforms. https://unfccc.int/process-andmeetings/the-paris-agreement/the-paris-agreement

[6] What is carbon neutrality and how can it be achieved by 2050? (2021, June 24). European Parliament. https://www.europarl.europa.eu/news/en/headlines/ society/20190926STO62270/what-is-carbonneutrality-and-how-can-it-be-achieved-by-2050

[7] Directorate-General for Environment, European Commission. (2019, April). The EU Environmental Implementation Review 2019 Country Report GERMANY. European Union.

[8] Germany. (2021b, September 15). Climate Action Tracker. Retrieved October 11, 2021, from https:/climateactiontracker.org/countries/germany/

[9] Prognos, Öko-Institut, Wuppertal Institut. (2021, June). Towards a Climate-Neutral Germany by 2045. How Germany can reach its climate targets before 2050. Agora Energiewende. https://www.agoraenergiewende.de/en/publications/towards-aclimateneutral-germany-2045-executive-summary

[10] The Consortium. (n.d.). Climate Action Tracker. https://climateactiontracker.org/about/theconsortium/

[11] Policies \& action. (n.d.). Climate Action Tracker. https://climateactiontracker.org/countries/germany/ policies-action/

[12] Circular economy action plan. (n.d.). European Commission.

https://ec.europa.eu/environment/strategy/circulareconomy-action-plan_en

[13] OECD. (2020, December). OECD Economic Surveys: Germany 2020. https://doi.org/10.1787/19990251

[14] Zhang, J. Zhang Y. Wen Y. (2021). Germany's Strategy, Goal and Influence to Promote Climate Governance. Environmental Protection, vol. 49, no. 10, 2021, pp. 65-68 